\title{
ĐĂC ĐIỂM LÂM SÀNG, CÂN LÂM SÀNG BÊ̂NH NHÂN VIÊM PHỔI DO COVID -19 ĐIỀU TRI TẠI BỆNH VIỆN BỆNH NHIỆT ĐỚI TRUNG ƯƠNG
}

\author{
Trần Văn Giang*, Nguyễn Thị Ngọc**
}

\section{TÓM TẮT}

Mục tiêu: Mô tả đặc điểm lâm sàng, cận lâm sàng ở 258 bệnh nhân viêm phổi do COVID-19 điều trị tại Bệnh viện Bệnh nhiệt đới Trung Ương. Đối tượng \& phương pháp: Mô tả cắt ngang 258 bệnh nhân viêm phổi do COVID-19. Kết quả: Các triệu chứng thường gặp của viêm phổi do COVID-19 gồm: ho $(87,6 \%)$, sốt $(81,8 \%)$, khac đờm $(31,4 \%)$, mêt mỏi $(41,1 \%)$, khó thở $(24,8 \%)$, đau họng $(33,3 \%)$, tiêu chảy $(26,0 \%)$; Các xét nghiệm: số lượng tế bào CD4 thấp hơn có ý nghĩa thống kê $(p<0,05)$ trong các trường hợp viêm phổi nặng do COVID-19; ngược lại AST, CRP, LDH, Ferrtin, D-dimer laai tăng cao có ý nghĩa ở các bệnh nhân viêm phổi nẳng do COVID-19. Đa số tổn thướng CT phổi gặp ở nhiều thùy phổi $(83,7 \%)$ tập trung chủ yếu thùy dưới phổi 2 bên với hình ảnh hay gặp là kính mờ $(74,4 \%)$ và tổn thương mô kẽ $(36,8 \%)$.

Tư' khóa: COVID-19, viêm phổi, ho.

\section{SUMMARY \\ CLINICAL AND SUBCLINICAL CHARACTERISTICS OF PATIENTS WITH PNEUMONIA CAUSED BY COVID-19 TREATED AT NATIONAL HOSPITAL OF TROPICAL DISEASES \\ Objective: Describe clinical features and paraclinical characteristics in 258 patients with pneumonia caused by covid-19 treated at National Nospital of Tropical Diseases. Materials and methodes: A cross-sectional study was carried 258 patients with pneumonia caused by COVID-19. Results. Common symptoms of pneumonia caused by COVID-19 include: cough $(87.6 \%)$, fever $(81.8 \%)$, sputum production (31.4\%), fatigue $(41.1 \%)$, shortness of breath $(24.8 \%)$, sore throat $(33.3 \%)$, diarrhea (26.0\%). Tests: CD4 cell count is significantly lower $(p<0.05)$ in severe cases of pneumonia due to COVID-19; In contrast, AST, CRP, LDH, Ferrtin, D- dimer were significantly increased in patients with severe pneumonia due to COVID-19. Most of the lung CT lesions were found in many lung lobes $(83.7 \%)$ and mainly focused on the lower lobes of the lungs on both sides with the common images being blurred glass (74.4\%) and interstitial pneumonia (36.8\%).}

Keywords: COVID-19, pneumonia, cough.

\section{I. ĐĂTT VẤN ĐỀ}

COVID - 19 là một đại dịch toàn cầu. Bệnh có biểu hiện lâm sàng đa dạng từ các triệu chứng tương tự cảm cúm thông thường (81\%) đến các

* Đai hoc Y Hà Nôi

Chịu trách nhiệm chính: Trần Văn Giang

Email: giangminh08@gmail.com

Ngày nhận bài: 20.9.2021

Ngày phản biên khoa hoc: 9.11.2021

Ngày duyệt bài: 22.11.2021 bệnh cảnh lâm sàng nặng hơn như suy hô hấp, ARDS, nhiễm khuẩn huyết (5\%), trong đó viêm phổi chiếm tỉ lê $76,4 \%$ với tỉ lệ tử vong ước tính 2,3\% [1]. Bệnh cảnh lâm sàng đa dạng làm cho việc chẩn đoán và điều trị gặp nhiều khó khăn. Tại Việt Nam, tính đến ngày 30/11/2021 tổng số bểnh nhân COVID-19 là 1.168.228 người, trong đó có 24.407 trường hợp tử vong. Các nghiên cứu trước đây thường chỉ tâp trung tìm hiểu biểu hiện lâm sàng, cận lâm sàng chung các bệnh nhân nhiếm COVID - 19. Hiện chưa có nhiều nghiên cứu lâm sàng và cận lâm sàng của các bệnh nhân viêm phổi do COVID-19. Chúng tôi tiến hành nghiên cứu này với mục tiêu: Mô tả đặc điểm lâm sàng, cận lâm sàng của bênh nhân viêm phôi do COVID-19 điều trị tại Bệnh viện Bênh nhiệt đới Trung ương từ tháng 1/2020 đến tháng 6/2021.

\section{II. ĐỐI TƯỢNG VÀ PHƯƠNG PHÁP NGHIÊN CỨU}

2.1. Đối tượng nghiên cứu. Gồm 258 bệnh nhân được chẩn đoán viêm phổi do COVID - 19 điều trị tại Bệnh viện Bệnh Nhiệt đới TW từ tháng 1/2020 đến tháng 6/2021.

Tiêu chuẩn chọn bệnh nhân: Bệnh nhân $>18$ tuổi, xét nghiệm PCR dương tính với SARSCoV-2 và có viêm phổi.

Tiêu chuẩn loại trừ: Phụ nữ có thai hoặc bệnh nhân có tổn thương phổi trước khi xét nghiệm PCR SARS-CoV-2 dương tính hoặc phát hiện nhiễm các loại virus khác, vi khuẩn, nấm tại thời điểm chẩn đoán viêm phổi.

2.2. Địa điểm và thời gian nghiên cứu. Tại Bệnh viện Bệnh Nhiệt đới TW từ tháng $1 / 2020$ đến tháng $6 / 2021$

\subsection{Phương pháp nghiên cứu}

Thiết kế nghiên cứu: nghiên cứu mô tả cắt ngang hồi cứu.

Cỡ mẫu nghiên cứu: tất cả bênh nhân đủ tiêu chuẩn vào nghiên cứu trong thời gian 1/2020 đến 6/2021 sẽ được thu thập.

Các thức thu thập thông tin: thông tin bệnh nhân được thu thập theo một mẫu bênh án. Bênnh nhân được chia thành 2 nhóm viêm phổi nhẹ và viêm phổi nặng để so sánh.

Phân tích và xử lý số liệu: số liệu được thu thập và xử lý bằng phần mềm SPSS 22.0

\section{KẾT QUẢ NGHIÊN CỨU}

Từ tháng $1 / 2020$ đến tháng 6/2021 chúng tôi 
thu thập được 258 bệnh nhân được chẩn đoán là viêm phổi do COVID -19 điều trị tại Bệnh viện Bệnh Nhiệt đới TW. Trong đó có 206 bệnh nhẩn viêm phổi nhẹ, 52 viêm phổi nặng và nguy kịch.

3.1. Đặc điểm chung của nhóm nghiên cứu

Bảng 1. Đặc điểm chung của nhóm nghiên cứu

\begin{tabular}{|c|c|c|c|}
\hline \multicolumn{2}{|c|}{ Đặc điểm chung } & \multicolumn{2}{|c|}{\begin{tabular}{l|c} 
Số lượng & Tỷ lệ \\
$(n=258)$ & $(\%)$
\end{tabular}} \\
\hline \multirow{5}{*}{ Tuổi } & $\leq 29$ & 47 & 18,2 \\
\hline & $30 \leq$ Tuối $\leq 49$ & 105 & 40,7 \\
\hline & $50 \leq$ Tuối $\leq 59$ & 47 & 18,2 \\
\hline & Tuối $\geq 60$ & 59 & 22,9 \\
\hline & $\begin{array}{l}\text { Mean } \pm \text { SD } \\
(\text { min-max })\end{array}$ & \multicolumn{2}{|c|}{$\begin{array}{c}45,6 \pm 5,9 \\
(18-89)\end{array}$} \\
\hline \multirow[t]{2}{*}{ Giới } & Nam & 119 & 46,1 \\
\hline & Nữ & 139 & 53,9 \\
\hline \multirow{8}{*}{$\begin{array}{l}\text { Bênh } \\
\text { nền }\end{array}$} & Đái tháo đường & 18 & 7,0 \\
\hline & Tăng huyết áp & 36 & 14,0 \\
\hline & Bênh phối mạn tính & 9 & 3,5 \\
\hline & Bệnh gan mạn tính & 11 & 4,3 \\
\hline & Bênh thân man tính & 10 & 3,9 \\
\hline & Bênh ác tính & 27 & 10 \\
\hline & Bệnh mạn tính khác & 23 & 8,9 \\
\hline & Không có bênh nên & 150 & 58 \\
\hline
\end{tabular}

Nhận xét: Tuối bệnh nhân trong nhóm nghiên cứu trung bình là $45,6 \pm 15,9$, thấp nhất là 18 tuổi, cao nhất là 89 tuổi, nhóm tuổi từ 30 đến 49 tuổi chiếm 40,7\%. Nam giới chiếm tỷ lệ $46,1 \%$. Các bệnh nền thường gặp là đái tháo đường chiếm $7 \%$, tăng huyết áp chiếm $14 \%$, bệnh phổi mạn tính chiếm 3,5\%, bệnh gan mạn tính chiếm 4,3\%, bệnh thận mạn tính chiểm $3,9 \%$, bệnh ác tính chiếm 10,5\%.

3.2. Đặc điểm lâm sàng bệnh nhân viêm phổi do COVID-19

Bảng 2. Đặc điểm lâm sàng bệnh nhân viêm phổi do COVID-19

\begin{tabular}{|c|c|c|}
\hline Triệu chứng & $\begin{array}{c}\text { Số lượng } \\
\text { (n=258) }\end{array}$ & $\begin{array}{c}\text { Tỷ lệ } \\
\text { (\%) }\end{array}$ \\
\hline Ho & 226 & 87,6 \\
\hline Sốt & 211 & 81,8 \\
\hline Mệt mỏi & 106 & 41,1 \\
\hline Đau hơng & 201 & 33,3 \\
\hline Khạc đờm & 81 & 31,4 \\
\hline Tiêu chảy & 67 & 26,0 \\
\hline Khó thở & 64 & 24,8 \\
\hline Đau cơ & 41 & 15,9 \\
\hline
\end{tabular}

\begin{tabular}{|c|c|c|}
\hline Đau đầu & 33 & 12,8 \\
\hline Buồn nôn, nôn & 8 & 3,1 \\
\hline Mất vị giác & 1 & 0,4 \\
\hline Thở nhanhh >25 lần/phút & 37 & 15,8 \\
\hline SPO2 <93\% & 33 & 12,8 \\
\hline Rì rào phế nang giảm & 28 & 10,9 \\
\hline Ran phối & 18 & 7,0 \\
\hline
\end{tabular}

Nhânn xét: Các triệu chứng lâm sàng bệnh nhân viêm phổi do COVID-19 thường gặp bao gồm: ho chiếm $87,6 \%$, sốt chiếm $81,8 \%$, mệt mỏi chiếm $41,1 \%$, đau họng chiếm $31,4 \%$, khạc đờm chiếm $31,4 \%$, khó thở chiếm $24,8 \%$, mất vị giác chiếm $0,4 \%$, thở nhanh $>25$ lần/phút chiếm $15,8 \%, \mathrm{SPO} 2<93 \%$ chiếm $12,8 \%$, rì rào phế nang giảm chiếm 10,9\%, ran phổi chiếm $7 \%$.

3.3. Đặc điểm xét nghiệm sinh hóa ở bệnh nhân viêm phổi do COVIID-19

Bảng 3. Đặc điểm xét nghiệm sinh hóa ở bệnh nhân viêm phổi do COVID-19

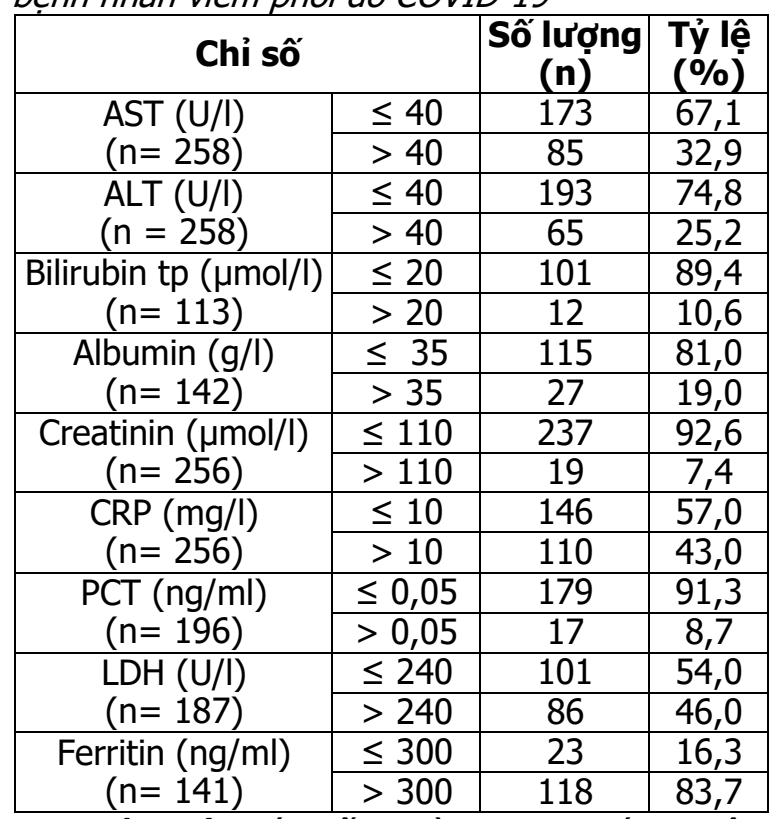

Nhân xét: Các bất thường trong xét nghiệm sinh hóa ở bệnh nhân viêm phổi do COVID-19 bao gồm: AST > $40 \mathrm{U} / \mathrm{l}$ chiếm 32,9\%, ALT > 40U/I chiếm $25,2 \%$, Bilirubin toàn phần $>20 \mu \mathrm{mol} / \mathrm{L}$ chiếm 10,6\%, CRP > $10 \mathrm{mg} / \mathrm{l}$ chiếm $43 \%$, PCT > $0,5 \mathrm{ng} / \mathrm{ml}$ chiếm $8,7 \%$, LDH > 240U/l chiếm $46 \%$, Ferritin $>300 \mathrm{ng} / \mathrm{ml}$ chiếm $16,3 \%$.

Bảng 4. So sánh một số xét nghiệm cận lâm sàng theo mức độ nặng

\begin{tabular}{|c|c|c|c|c|c|}
\hline \multirow{2}{*}{ Chỉ số } & \multicolumn{2}{|c|}{ Viềm phối } & Viềm phối nặng, nguy kịch & \multirow{2}{*}{ p } \\
\cline { 2 - 5 } & $\mathbf{n}$ & Mean (Min - Max) & $\mathbf{n}$ & Mean (Min - Max) & \\
\hline CD4 (cell/ml) & 125 & $544(82-1704)$ & 28 & $246(81-738)$ & $\mathbf{0 , 0 0 0}$ \\
\hline CRP $(\mathrm{mg} / \mathrm{l})$ & 205 & $4,7(0,4-220,7)$ & 52 & $39,2(0,6-304,4)$ & $\mathbf{0 , 0 0 0}$ \\
\hline Creatinin $(\mu \mathrm{mol} / \mathrm{l})$ & 204 & $75,1(29,0-863,0)$ & 52 & $79(51-170)$ & 0,664 \\
\hline AST $(\mathrm{UI} / \mathrm{l})$ & 206 & $28,3(11,3-178,0)$ & 52 & $44,4(27,1-531,9)$ & $\mathbf{0 , 0 0 0}$ \\
\hline
\end{tabular}




\begin{tabular}{|c|c|c|c|c|c|}
\hline ALT (UI/l) & 206 & $22,7(2,5-280,9)$ & 52 & $36,8(7,8-912,8)$ & $\mathbf{0 , 0 0 0}$ \\
\hline LDH (UI/l) & 140 & $198(1,5-786,7)$ & 47 & $323,5(142-1294)$ & $\mathbf{0 , 0 0 0}$ \\
\hline Ferritin (ng/ml) & 96 & $615(9,6-2000)$ & 45 & $1553(7,5-2000)$ & $\mathbf{0 , 0 0 0}$ \\
\hline D - Dimer (ng/ml) & 200 & $396(22-16459)$ & 52 & $817(113-23375)$ & $\mathbf{0 , 0 0 0}$ \\
\hline
\end{tabular}

Nhận xét: Trong viêm phối nặng do COVID - 19 thì số lượng CD4 thấp hơn có ý nghĩa thống kê so với viêm phổi nhẹ do COVID - 19 với $p<0,05$. Các giá trị CRP, men AST, ALT, LDH, Ferritin, Ddimer cao hơn có ý nghĩa thống kê giữa nhóm viêm phổi nặng do COVID - 19 so với viêm phổi nhẹ do COVID - 19 với $p<0,05$.

3.4. Đặc điểm tổn thương trên CT phổi ở bệnh nhân viêm phổi do COVID-19

Bảng 5. Đặc điểm tổn thương trên CT phổi ở bệnh nhân viêm phổi do COVID-19

\begin{tabular}{|c|c|c|c|}
\hline \multicolumn{2}{|c|}{ Đặc điểm tổn thương } & $\begin{array}{l}\text { Số lượng } \\
(\mathrm{n}=258)\end{array}$ & $\begin{array}{l}\text { Tỷ lệ } \\
(\%)\end{array}$ \\
\hline \multirow{5}{*}{$\begin{array}{l}\text { Vị trí tổn } \\
\text { thương }\end{array}$} & Thùy trên $\mathrm{P}$ & 89 & 34,5 \\
\hline & Thùy giữa & 81 & 31,4 \\
\hline & Thùy dưới P & 213 & 82,6 \\
\hline & Thùy trên $T$ & 98 & 38 \\
\hline & Thùy dưới T & 224 & 86,8 \\
\hline \multirow{2}{*}{$\begin{array}{l}\text { Mức độ tổn } \\
\text { thương }\end{array}$} & 1 thùy & 42 & 16,3 \\
\hline & Đa thùy & 216 & 83,7 \\
\hline \multirow{6}{*}{$\begin{array}{l}\text { Đằc điểm } \\
\text { tổn thương }\end{array}$} & Kính mờ & 192 & 74,4 \\
\hline & Nốt mờ & 68 & 26,4 \\
\hline & Lát đá & 28 & 10,9 \\
\hline & Đông đặc & 87 & 33,7 \\
\hline & $\begin{array}{l}\text { Tốn thương } \\
\text { mô kẽ }\end{array}$ & 95 & 36,8 \\
\hline & Khác & 28 & 10,9 \\
\hline
\end{tabular}

Nhận xét: Về vị trí và mức độ tồn thương trên CT phổi: tổn thương đa thùy $83,7 \%$, thùy dưới phải $82,6 \%$, thùy dưới trái $86,8 \%$. Về đăc điểm tổn thương trên $\mathrm{CT}$ phổi: kính mờ $74,4 \%$, tổn thương mô kẽ $(36,8 \%)$, đông đặc 33,7\%, nốt mờ 26,4\%.

\section{BÀN LUẬN}

4.1. Đặc điểm chung của nhóm nghiên cứu. Tuổi trung bình của bệnh nhân trong nghiên cứu là 45,6 $\pm 15,9$, cao nhất 89 tuổi, thấp nhất là 18 tuổi, nhóm tuổi bệnh nhân < 60 chiếm đa số $(77,1 \%)$ (Bảng 1$)$. Kết quả này tương tự với nghiên cứu của Kunhua Li (2020) độ tuổi trung bình của bệnh nhân là 45,5 tuổi, nghiên cứu của Gemin Zhang (2020) với tuối trung bình là 49 tuổi (> 50\% bệnh nhân từ 40 60 tuổi) [2]. Như vậy, viêm phổi COVID-19 có thể gặp ở mọi đối tượng, mọi lứa tuổi khác nhau.

Trong tổng số 258 bệnh nhân viêm phổi COVID-19, nam là 119 người $(46,1 \%)$ thấp hơn nữ giới 139 người $(53,9 \%)$. Dữ liệu phân tích theo sáng kiến nghiên cứu $50 / 50$ của Global Health đã trình bày một cái nhìn tổng quan về dữ liệu phân tách theo giới tính từ các quốc gia trên toàn thế giới, chứng minh rõ ràng số ca mắc bệnh ở phụ nữ và nam giới tương tự nhau, nhưng tỷ lệ tử vong ở nam giới lại tẳng lên. Nhiều yếu tố như phản ứng miển dịch, hormone giới tính, yếu tố sinh lý, lối sống hành vi văn hóa xã hội...có thể ảnh hưởng đến tiên lượng, kết quả điều trị giữa 2 nhóm bệnh nhân nam, nữ.

4.2. Đặc điểm lâm sàng bệnh nhân viêm phổi do COVID-19. Trong nghiên cứu của chúng tôi, các triệu chứng thường gặp của viêm phổi do COVID-19 là ho $(87,6 \%)$, sốt $(81,8 \%)$, khạc đờm (31,4\%), khó thở (24,8\%) (Bảng 2). Ngoài các triệu chứng thường gặp trong viêm phổi, một số triệu chứng ngoài phổi cũng có thể gặp trong viêm phổi COVID-19 bao gồm mệt mỏi $(41,1 \%)$, đau họng $(33,3 \%)$, tiêu chảy $(26 \%)$, đau cơ $(15,9 \%)$, đau đầu $(12,8 \%)$, buồn nôn, nôn $(3,1 \%)$ và có 1 trường hợp ghi nhận mất vị giác $(0,4 \%)$ (Bảng 2$)$. Các thí nghiệm trên tế bào đã chỉ ra rằng vi rút SARS-CoV và SARS-CoV-2 có khả năng lây nhiễm tế bào ruột. Sự sao chép tích cực đã diễn ra ở đường ruột của dơi và con người. Calprotectin trong phân - một dấu ấn sinh học đáng tin cậy cho phép phát hiện tình trạng viêm ruột trong các bệnh viêm đại tràng và nhiễm trùng đại tràng đã được tìm thây ở một số bệnh nhân. Điều này cung cấp bằng chứng cho thấy SARS-CoV-2 tạo ra phản ứng viêm trong ruột. Những phát hiện này giải thích tại sao các triệu chứng tiêu hóa lại thây được ở một nhóm bênh nhân và tai sao RNA virus có thể được tìm thấy trong mẫu phết trực tràng ngay cả khi xét nghiệm phết mũi hầu họng đã âm tính. Ở những bệnh nhân bị tiêu chảy, RNA vi rút trong phân được phát hiện với tần số cao hơn. Như vậy rất nhiều các triệu chứng có thể gặp ở bệnh nhân viêm phổi COVID-19, có thể gặp nhóm triệu chứng phổ biến ở hệ hô hấp như ho, khó thở, sốt và các nhóm triệu chứng khác bao gồm triệu chứng cơ xương khớp (đau cơ, đau khớp, đau đầu, kiệt sức), các triệu chứng đường tiêu hóa (đau bụng, buồn nôn, tiêu chảy)

4.3. Đặc điểm xét nghiệm sinh hóa ở bệnh nhân viêm phổi do CoVID-19. Trong nghiên cứu của chúng tôi, các bất thường sinh 
hóa máu thường gặp bao gồm tăng Ferritin $(83,7 \%)$, giảm Albumin máu (81\%), tăng LDH $(46 \%)$, tăng CRP $(43 \%)$, tăng AST $(32,9 \%)$, tăng $\operatorname{ALT}(25,2 \%)$, tăng Billirubin $(10,6 \%)$, tăng PCT $(8,7 \%)$, tăng Creatinin $(7,4 \%)$. Men gan AST và ALT trong nhóm bệnh nhân viêm phổi nặng, nguy kịch do COVID-19 trong nghiên cứu tăng cao so với nhóm bệnh nhân viêm phổi do COVID-19 (Bảng 4). Nghiên cứu này của chúng tôi tương tự kết quả trong nghiên cứu của tác giả Nabavi S (2021). Tác giả này đưa ra giả thuyết rằng khi tình trạng thiếu oxy tăng cao ở bệnh nhân viêm phổi nặng có thể góp phần gây tổn thương tế bào gan và từ đó giải phóng enzyme gan, đặc biệt là AST [3]. Tuy nhiên cũng có báo cáo trong 1 số nghiên cứu cho rằng sự hủy hoại tế bào gan dẫn đến tăng men gan là do vi rút xâm nhập trực tiếp vào tế bào gan và gây tổn thương [4]. Han et al đã báo cáo rằng AST có thể là một yếu tố nguy cơ độc lập với các trường hợp nhiểm COVID-19 nặng và nguy kịch.

Một phát hiện quan trọng khác trong nghiên cứu của chúng tôi là mức CRP tăng cao hơn rõ rệt ở bệnh nhân viêm phổi nặng, nguy kịch do COVID-19. Kết quả của chúng tôi tương tự với nghiên cứu của Nabavi S (2020) [3]. Tác giả chỉ ra rằng CRP là có liên quan độc lập với mức độ nghiêm trọng của bệnh, với mức CRP > 37,3 $\mathrm{mg} / \mathrm{l}$ được cho là có liên quan đến đến viêm phổi nặng hơn và kết quả điều trị kém hơn [5].

Trong nghiên cứu của chúng tôi (Bảng 4) cũng cho thấy LDH tăng cao, D-dimer tăng cao, số lượng tế bào lympho giảm, CD4 giảm cũng là yếu tố nguy cơ để dự báo tình trạng viêm phổi nặng, nguy kịch ở bệnh nhân COVID-19. Trong nhiều nghiên cứu khác trên thế giới cũng chỉ ra rằng số lượng tế bào lympho đặc biệt là $C D 3$, CD4, CD8 giảm và LDH cao, D-dimer tăng cao như 1 yếu tố dự báo cho mức độ nghiêm trọng của bệnh [6].

4.4. Đặc điểm tổn thương trên CT phổi ở bệnh nhẩn viêm phổi do COVID-19. Trong nghiên cứu của chúng tôi (Bảng 5) cho thây tôn thương phổi do COVID-19 chủ yếu là tổn thương đa thùy $(83,7 \%)$ hay gặp thùy dưới 2 bên (> $80 \%$ ) trong đó hình ảnh điển hình là kính mờ $(74,4 \%)$. Số lượng tổn thương các thùy là 1 yếu tố dự báo mức độ viêm phổi của bệnh nhân COVID-19 (Bảng 3.10). Kết quả này cũng tương tự trong nghiên cứu của Nabavi S (2021) [3]. Guan WJ (2020) đã báo cáo 1099 trường hợp COVID-19 thì có $96 \%$ bệnh nhân có bất thường về hình ảnh CLVT ngực [7]. Đối với bệnh nhân
COVID-19 Xquang thường thấy tổn thương thâm nhiễm hai bên, nhưng có thể bình thường ở giai đoạn sớm. CLVT ngực chẩn đoán nhậy hơn và đặc hiệu hơn. Hình ảnh CLVT là thâm nhiễm, kính mờ, đông đặc dưới phân thùy. Cũng có thế có hình ảnh bất thường X-quang ngực trên bệnh nhân không triệu chứng hay không có triệu chứng hô hấp dưới. Thực tế trong thực hành đã sử dụng hình ảnh CLVT để chẩn đoán COVID-19 trong trường hợp nghi ngờ nhưng test chẩn đoán sinh học phân tử âm tính. Nhiều bệnh nhân sau đó dương tính khi làm lại test.

\section{KẾT LUẬN}

- Đặc điểm lâm sàng của bệnh nhân viêm phổi do COVID-19: ho $(87,6 \%)$, sốt $(81,8 \%)$, khạc đờm $(31,3 \%)$ và mệt mỏi $(41,1 \%)$, khó thở $(24,8 \%)$, tiêu chảy $(26 \%)$.

- Đặc điểm cận lâm sàng của bệnh nhân viêm phổi do COVID-19: Số lượng tế bào CD4 thấp hơn có ý nghĩa thống kê của nhóm bệnh nhân viêm phổi nặng do COVID-19. Ngược lại men gan, CRP, LDH, Ferrtin, D-dimer lại tăng cao có ý nghĩa thống kê ở nhóm bệnh nhân viêm phổi nặng do COVID-19 $(p<0,05)$. Đa số tổn thương CT phổi gặp ở nhiêuu thùy phổi $(83,7 \%)$ tập trung chủ yếu thùy dưới phổi 2 bên ( $>80 \%)$ với hình ảnh hay gặp là kính mờ $(74,4 \%)$ và tổn thương mô kẽ $(36,8 \%)$.

\section{TÀI LIỆU THAM KHẢO}

1. Zunyou W and Jennifer M.M. (2020). Characteristics of and important lessons from the coronavirus disease 2019 (COVID-19) outbreak in China: summary of a report of 72314 cases from the Chinese Center for Disease Control and Prevention. Jama. 323(13):1239-1242.

2. Kunhua Li, Jiong $\mathbf{W}$, Faqi $\mathbf{W}$, et al. (2020). The clinical and chest CT features associated with severe and critical COVID-19 pneumonia. Investigative radiology.

3. Nabavi $S$, Javidarabshahi $Z$, Allahyari $A$, et al. (2021). Clinical features and disease severity in an Iranian population of inpatients with COVID-19. Scientific Reports. 11(1):1-9.

4. Zhang $C_{\text {, Shi }} \mathbf{L}$ and Wang F-S. (2020). Liver injury in COVID-19: management and challenges. The lancet Gastroenterology \& hepatology. 5(5):428-430.

5. Wang L. (2020). C-reactive protein levels in the early stage of COVID-19. Medecine et maladies infectieuses. 50(4):332-334.

6. Xiaochen L, S. X, Muqing Y, et al. (2020). Risk factors for severity and mortality in adult COVID19 inpatients in Wuhan. Journal of Allergy and Clinical Immunology. 146(1):110-118.

7. Guan W, Z.-y. N, Yu H, et al. (2020). Clinical characteristics of 2019 novel coronavirus infection in China. MedRxiv. 